\title{
THE FAILED FACTORS ON TELLING THE FOLKTALES APPLIED BY ENGLISH TEACHERSON STUDENTS' LEARNING PROCESS
}

\author{
La Mido ${ }^{1)}$ \& Wa Ode Nur Mizrahtin Muriman ${ }^{2)}$ \\ $\left(\right.$ Staf Pengajar ${ }^{1)}$ dan Mahasiswa ${ }^{2)}$ Program Studi Pendidikan Bahasa Inggris, Unidayan)
}

\begin{abstract}
ABSTRAK
Penelitian ini bertujuan untuk menjelaskan secara rinci faktor kegagalan penggunaan cerita rakyat dalam proses pembelajaran di SMP Negeri 4 Baubau.Penelitian ini menggunakan penelitian qualitative dengan metode studi kasus. Untuk memperoleh data, penulis menggunakan dua jenis instrumen yaitu interview dan angket. Teknik yg digunakan dalam menganalisis data, penulis menggunakan teknik reduksi, penyajian dan verifikasi. Hasil penelitian ini menunjukan bahwa diantara enam faktor luar yang menyebabkan kegagalan terhadap penggunaan cerita rakyat dalam proses pembelajaran, lingkungan kelas yang kurang nyaman adalah faktor yang paling utama yang menyebabkan kegagalan siswa dalam proses pembelajaran dengan menggunakan cerita rakyat. Faktor yang berikutnya adalah gangguan dari teman sekelasnya pada saat proses pembelajaran berlangsung sehingga kurang konsentrasi terhadap pelajaran.
\end{abstract}

Keywords: Failed Factors, Folktales

\section{INTRODUCTION}

Folktales are stories influenced by people traditions and customs. They are universal especially among the people in spite of their advancement and the level of socialization (Kolawole in Joshua (2013: 237)). Folktales are also known as telling tale. It is used by oral artist to provide relaxation and teaching moral lesson. Taylor E, (2000) mentioned folktale is used for several kinds of stories. Most narrowly, it is a traditional stories that has been passed on by word of mouth. It was told from parent to child over many generation. For example; animal that can talk like human and people who can fly and disappear.

Telling the folktales are important activity because it gives some benefits for the children. The benefits of folktales help the children' imagination, improve the children' intelligence and as a media in building ethic. It is also used as a media in building life values, stimulate reading interest and build nearness between the parents with the children.

Telling folktales is one of the techniques in teaching English in Junior High School. By using the story, the teacher can motivate the students to learn English on what they read or heard.

Storytelling relates to current concerns about our future because most stories focus on the earth, how it was created, and the problems that can arise when we forget the importance of living in harmony with it and each other (Gersie, 1992). Joshua (2013: 238) said that folktale could be regarded as a fictitious story narrated by elders to children to guide them towards cherished habits and also to entertain.

Based on the above explanation, the writer was interested to conduct a study on failed factors telling the folktale applied by teachers on students' learning process with its objetcive was to explore the failed factors on the use of folktale in learning process. This research just focused the external failed factors of telling the folktale in learning process.

\section{Theoritical Review}

Taylor E, (2000) explaines that folktales from the contents point of view divided into 5 types, they are: 
a. Myth is a kind of folktales that tell about the life of ghost, devil, or davit.

b. Legend is a kind of folktales that created by a society that relate with the natural condition and the name of a land.

c. Sage is a kind of folktales where inside of it there is history elements, but it is hard to believe about the truth because the history elements driven by fantasy elements.

d. Fable is a kind of folktales that talk about the animal's life as the story.

e. Parable is a kind of folktales where the story focused on education aspect.

Folktale is the best media in educating the children. It is because the story is not only entertaining but it is also capable of holding students attention while they learn important concepts, attitudes and skill. So that, it is possible to create the children who have good behavior and good intelligence. It also supported by Rocha O (1992) about the benefits of telling folktales, they were:

1) Folktales help the children to use their imagination

Imagination is very important for the children's cognitive development. The imagination will help children to think creatively in face and plan the problem solving that they faced. Imagination will also make the children competent in communicate with another people.

When listening to a folktale, the mind of the children will be stimulated to describe the situation as they heard. The vocabulary that they heard will improve the children's vocabulary. This vocabulary will help the children to express their feelings easily or anything that they think about. As a result, they will become more competent in communication with the people around them.

2) As media in building ethic and life values

Through the characters in folktales, our children can learn the values of honesty, humility, empathy and also the attitude to help each other. In telling folktales, the moral messages and ethics lessons that we want to give not overload the child's feelings. Therefore, as parents we have to be clever to choose the content of the folktales.

3) Stimulate children reading interest

After the children heard one folktale, they usually interest to hear the other folktales. We can use this opportunity to introduce a book as a "fun friend" or sometimes the parents could bring the children to the book store and let them choose their own book, it will more effective to stimulate the children reading interest.

4) Building nearness between the parents/teacher with the children/the students

Time of telling folktales will be a media for the children and parents in get together after a busy day of many activities. The experience in telling folktales together will be a sign for the children that their parents love and care about them.

According to Carole, (1999) there are some inhibition factors that caused failure on learning process. They are classified into internal and external factors.

1. External factors

External factor is factors that come from students' environment. External factors can be divided into some kinds such as:

a. Teacher interaction

Carole, (1999) states that a teacher who never had an interaction with the students made the learning processes not affective. It was because the students felt there's a distance between them and the teacher, so that it was very difficult for the students to participate in the learning process. 
b. Teacher way in teaching

A teacher who always teach with new way would made the learning process became more interested. So that it would increase the learning process and the students' motivation in the learning process.

c. Learning method

A method that always make the teacher as the centre in learning process made the students felt bored, passive, sleepy and not interested in the learning process. It caused the learning process failure.

Wainryb R, (2003) argues that in teaching language especially foreign language, we could not separate from vocabulary. Vocabulary is every word that understood by people. When the learners had a lot of vocabularies, it was easy for them to convey and accepted information. However, when they did not have a lot of vocabulary, it would be something difficult for them to convey and accepted information.

\section{METHOD}

The design of this research was qualitative research. This qualitative research applied case study method based on the phenomena that the researcher got at the preobservation. Gay (2006) stated that case study used to describe and interpret what is there about the condition or relationship, the opinion that have been grown, the process is in in progress. Similar to Gay, Cresswell J, (2008) also argues that case study is an examination of specific phenomena such as a program, an event, a process, a person, an institution or a social group.

This research was conducted in SMPN 4 Baubau. The respodents of this research were the students who didn't have any development after the teacher applied telling folktales in the students learning process.

In order to facilitate the data collection, the researcher used two instruments below :

\section{Interview}

Interview is a purposeful interaction in which one person is trying to abtain information from another source. Interview permit researcher to obtain important data they cannot acquire from observation alone. Interview can explore and probe participants' responses to gather more in-depth data about their experiences and feelings (Gay et al, 2006).

O'Donoghue T, (2007) states that the activity in qualitative data analysis is interactive way and continue until the data surfeited. The activities in data analysis are data reduction, data display, and conclusion. Data reduction is the process of selecting, focusing, simplification and transformation of raw data that emerged from the written record in the field. This activity includes summary, codes, and theme; choose the main things or memo. Reduction is a part of the data analysis because it is a stage where researcher chooses and encodes the data that is considered important and determining pattern of some outcomes data collection. O'Donoghue T, ( 2007) further explains that the most frequent form of display data for qualitative research data in the past has been narrative. Looking at displays help us to understand what is happening and to do some things -further analysis or caution on that understanding. In data display, besides using narrative text, the researcher also can use graphic, matrix, network, and chart. The conclusion in qualitative research is a new discovery that never exists before. The discovery form can be a description of an object that's not clear before but after 
researched the discovery become clear, there is a causal correlation or interactive, hypothesis or theory.

\section{Questionnaire}

According to Gay, (2006) questionnaire is technique of data collection by giving questions to respondent to be answered. The aim of giving questionnaire was to found out the failed factors that related with the variable of this research. The questionnaire used was Likert Scale. Each item of the questionnaire consisted of 5 options. The number of questionnaires was 5 for the highest score and 1 for the lower score.

\section{FINDING AND DISCUSSION}

\section{A. Finding of the Research}

Based on the result of the data collection about the failed factors on telling folktales applied by teacher in students learning process, the researcher found a description about the result:

\section{External Factors}

The external factors in this research were:

a. Method

Based on the data analysis of questionnairesshowedthat thetotal score of method factor was 28 withpercentage result $9.5 \%$. This percentage categorized less inhibited. It could be concluded that the method factor was less inhibited in the learning process that caused telling folktales failure.

b. Teacher Way in Teaching

Based on data collectionby usingquestionnairesshowedthat thetotal scoreof teacher way in teaching factor was 31 withpercentage result $10.5 \%$. This percentage categorized less inhibited. It could be concluded that the teacher way in teaching factor was less inhibited in the learning process that caused telling folktales failure.

c. The topic of a story

Based on the questionnaires data analysis showedthat thetotal score of the topic of the story was 24with percentage result $8.12 \%$. This percentage categorized less inhibited.
It could be concluded that the factor on the topic of the story was less inhibited in the learning process that caused telling folktales failure.

d. Class Environment

Based on data collectionby usingquestionnairesshowedthat thetotal score of class environment factor was38withpercentage result $12.83 \%$. This percentage categorized quite inhibited. It could be concluded that the class environment factor was quite inhibited in the learning process that caused telling folktales failure.

e. The influence of friends

Based on questionnaires data analysis showed that the total score of the influence of friend's factor was 34 with percentage result $11.5 \%$. This percentage categorized quite inhibited. It could be concluded that the influence of friend's factor was quite inhibited in the learning process that caused telling folktales failure.

f. Teacher Interaction

Based on data collectionby usingquestionnairesshowedthat thetotal score of teacher interaction factor was 22 with percentage result $7.43 \%$. This percentage categorized less inhibited. It could be concluded that the teacher interaction factor was less inhibited in the learning process that caused telling folktales failure. 
Overall, theexternal factorsthat the learning process were presented inthe influence the telling folktales method failed in following image.

Figure 4.1: The Failed on External factors

\section{External Factors}

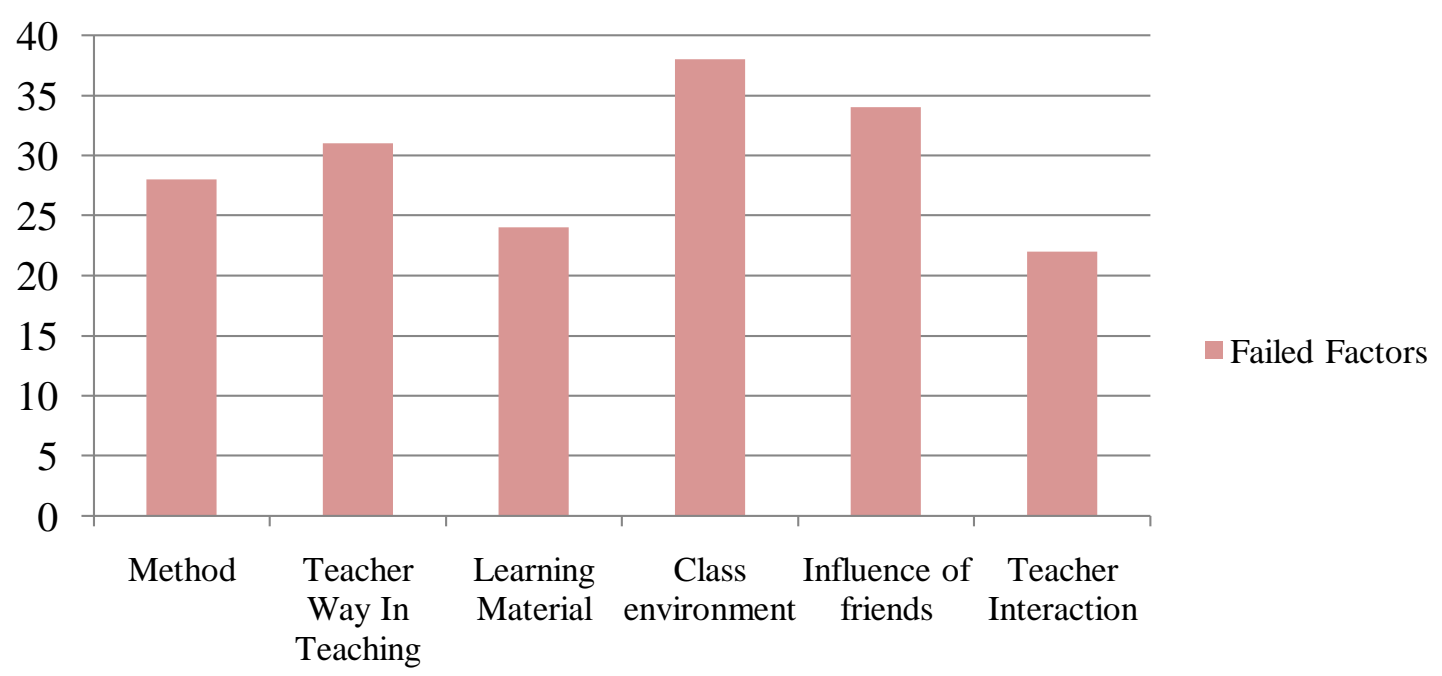

Based on the pictureabove showed thatthe highest total score of the failed factors on telling folktales was the factor of class environment with value 38 .

\section{B. Finding of the Interview}

The failed on external factors in learning process consist of method, teacher way in teaching, the topic of the story, classroom environment, the influence of friends and teacher interaction were presented in the following quotations.

"oh itu, kalau menurutku yang bikin kurang menarik itu to kakak, kayak bagaimanae, karena kalau bercerita begitu kita hanya mendengarkan saja, mana saya tidak terlalu tahu juga artinya"

Based on the interviewed result with NA on August $13^{t h}, 2015$ about the method factor, she said that the method was not interested. It was because she could only listen to the teacher. She also said that it became more difficult because she could not understand the meaning. (Interview with NA on August $\left.13^{t h}, 2015\right)$.Another reason also stated by a student named LW relate with the teacher way in teaching factor, based on the interview result, she said:

"oh itu, iniee soalnya guruku itu kalau dia cerita kayak tidak ada ekspresinya itu baru kalau dia cerita itu datar-datar saja suaranya makanya saya tidak terlalu tertarik."

Based on the above quotation with LW, she said that the teacher way on telling the fable story was not interested. It was because the teacher did not show face expression and his voice was flat on telling the story. (Interviewed with LW on August $\left.13^{\text {th }}, 2015\right)$.Another statement also expressed by another students named LAS relate with the topic of the story, based on the interviewed result, he said:

“ soalnya tidak terlalu banyak ceritacerita tentang masa lalu itu dank, hanya dia cerita-cerita tentang kisahnya saja dank, tentang masa lalunya"

Based on the opinion, LAS said that the topic of the story was not interested. It was 
because most of the story only talked about the teacher's experienced not about the fable story. (Interviewed with LAS on August 19 ${ }^{\text {th }}$, 2015).Another thing also stated by another student named NA relate with the teacher interaction based on the results of interviews conducted the researcher on August $13^{\text {th }}$, 2015, she said:

"oh itu, memang kak, waktu guruku dia cerita itu dia hanya cerita-cerita saja jarang juga dia mau tanya kita mengerti tentang ceritanya atau tidak."

Based on the interviewed with NA, she said that it was very rarely for the teacher to had an interaction with them, for example asked them whether they understood about the story or not. (Interviewed with NA on August $\left.13^{\text {th }}, 2015\right)$. Based on the interviewed result relate with the classroom environment and the influence of friends factors, were presented in the following quotations.

"oh itu kakak, jadi to yang bikin kelasku kurang nyaman waktu itu karena itue kakak, kelasku itu dia kotor baru bukan itu saja, kan kelasku itu di pinggir jalan, jadi dia ribut kalau ada motor sama mobil yang lewat."

"iya kasihan kakak, terus to waktu guruku dia masih bercerita itu to yang bikin kurang konsentrasi juga karena teman-temanku di kelas juga dia ribut akhirnnya begitu mi, saya jadi malas mi juga perhatikan guruku."

"iya kak, soalnya waktu itu banyak juga teman-temanku juga denk yang ajak saya cerita, makanya saya tidak terlalu perhatikan mi juga guruku."

Based on the interviewed result with LW on August 13 ${ }^{\text {th }}, 2015$, she said that her classroom was not comfortable. It was because the class was dirty. Not only that, the class location that near with the road was noisy by the sounds of the motorcycles and cars that passed the road. She also explained that she couldn't concentrate because the class was noisy by the other students who talked around when the teacher told fable story. Beside that the influence of friends who asked her to talk with them made her lazy to pay attention to the teacher. (Interviewed with LW on August $\left.13^{\text {th }}, 2015\right)$. The same thing also said by $A M H$ relate with the class environment on the interviewed conducted by the researcher on August 19 ${ }^{\text {th }}, 2015$, he said:

"kadang kalau ada motor yang lewat kita tidak konsentrasi lagi , apa lagi waktu itu ada demo, langsung balikeee"

Based on the quotation with AMH, he said that when motorcycles passed near the class made him couldn't concentrate, moreover there was a demonstration at the time. (Interviewed with AMH on August $\left.19^{\text {th }}, 2015\right)$. In addition, similar reasons also said by IM, he said:

"yang bikin kurang nyaman di kelas karena teman-teman dia bercerita"

"karena ceritanya dia menarik,ya saya ikut mi juga cerita sama temanku"

Based on the interviewed result, IM said that the class was not comfortable. It was because the class was noisy by the other students who talked around. $\mathrm{He}$ also explained that the story of his friends was interested made him talked to them. (Interviewed with IM on August 23 ${ }^{\text {th }}, 2015$ ).

\section{Discussion}

The external factors discussed on this part were the method, the manner of teacher's presentation, the topic, classroomenvironment, friends' influence, andteacher'sinteraction.

In the questionnaire data analysisshowedthat method and teacher way in teaching factors got total score 28 and 31 withpercentages result $9.5 \%$ and $10.5 \%$. These percentages were categorized less inhibited. It could be concluded that the method and teacher way in teaching factors were less 
inhibited in the learning process that caused telling folktales failure.

Based on the interviewed results, showed that the students did not like the learning method. It was because the method only focused on the teacher, so the students became passive. The students also explained that they felt bored because the teacher's way on telling the fable story was not interesting. It was because the teacher did not show face expression and his voice was flat on telling the story. These things influence by the learning method and teacher's way in teaching factors of the external factors.

Carole, (1999)mentioned that a method that always make the teacher as the centre in learning process made the students felt bored, passive, sleepy and not interesting in the learning process. It caused the learning process failure. Taylor E, (2000) said that there were some factors that affected on telling folktales became more interesting. Some of them were face expression, body movement and voice. On telling folktales, the storyteller must show face expression because it made the audience more focused and enjoyed the story. The storyteller's movement on telling folktales supported the describing of the story. The different intonation also helped the children to distinguish between the sounds of single character with other figure.

In the questionnaire data analysisshowedthat the topic of the story and teacher interaction factors got total score 24 and 22 withpercentages result $8.12 \%$ and $7.43 \%$. These percentages were categorized less inhibited. It could be concluded that the topic of the story and teacher's interaction factors were less inhibited in the learning process that caused telling folktales failure.
Based on the interviewed result, the students stated that the topic of the story was not interesting. It's because the topic only focused on the teacher's experience. The students also explained that it was very rarely for the teacher to have an interaction with the students. These things influence by the teacher's interaction factor of the external factors. Carole, (1999) stated that a teacher who never had an interaction with the students made the learning process not affective. It was because the students felt a distance between them and the teacher so that it was very difficult for the students to participate in the learning process.

Furthermore, based on the questionnaire result showed that the class environment andthe influence of friends factors gottotal score 38 and34withpercentages $12.83 \%$ and $11.5 \%$. These percentages were categorized quite inhibited. It could be concluded that the class environmental and the influence of friend factors were quite inhibited in the learning process that caused telling folktales failure.

Based on the interviewed result showed that, the classroom was not comfortable. It was because the class was dirty. Not only that, the class location that near with the road was noisy by the sounds of the motorcycles and cars that passed the road. The students also explained that they couldn't concentrate because the class was noisy by the other students who talked around when the teacher told fable story. Beside that, the influence of friends who asked the student to talk with them made the student lazy to pay attention to the teacher. These things influenced by the class environment factor of the external factors.

\section{CONCLUSION}

The external factors consist of method, learning material, teacher way in teaching, and the teacher interaction factors got total percentages $9.5 \%, 10.5 \%, 8.12 \%$, and $7.43 \%$. They were categorized less inhibited in the learning process that caused telling folktales failure. In other side, the classroom environment and the influence of friends factors got total percentage $12.83 \%$ and $11.5 \%$. They were categorized quite 
inhibited in the learning process that caused telling folktales failure. The highest score in external factors was class environment factor. Based on the interviewed result, showed that the classroom was not comfortable. It was because the class was dirty. Not only that, the class location that near with the road was noisy by the sounds of the motorcycles and cars that passed the road. The students also explained that they couldn't concentrate because the class was noisy by the other students who talked around when the teacher told fable story. Beside that, the influence of friends who asked the student to talk with them made the student lazy to pay attention to the teacher. Finally these things could make failure on telling folktales applied by teacher in students learning process.

\section{Suggestion}

It is very important to keep the students focused and concentrated in learning process by creating comfortable situation so that they become more interested and motivated in the learning process. By this way, the learning process can produce good result and the students could get the knowledge that they need for their better future.

\section{BIBLIOGRAPHY}

Carole. 1999. Teaching Language Arts. California State University, Long Beach.

Creswell, J. 2008. Educational Research: Planning, Conducting and Evaluating Quantitaive and Qualitative Research. University of nebraskaLincoln.

Gay, et al.2006. Educational Research. New Jersey: Pearson Prentice Hall.

Gersie, A. 1992. Storytelling in Times of Change, p.1. Http://www.unesco,org/education/tlsf/ mods/theme d/ $\bmod 21 . \mathrm{html}$. Downloaded on May $18^{t h}, 2015$.

Joshua. 2013. Folktales as Material Resources For Movie Production in Selected Nollywood Movies. International Journal of English and Literature 4(5). 237-238. Download from http://www.academicjournals.org/IJE $\underline{\mathrm{L}}$ on May $18^{\text {th }}, 2015$.
Merriam, S. 1998. Qualitative Research and Case Study Application in Education. San Francisco : Jossey-Bass Publisher.

O’Donoghue T, ( 2007). Planning Qualitative Research. New York, Madison Ave.

Rocha, O. 1992. Benefit of using Stories in EFL Context. Asian EFL Journal. Download from http://www.academicjournals.org/EF $\underline{\mathrm{L}}$ on April10 $0^{\text {th }}, 2015$.

Sugiyono. 2011. Metode Penelitian Kuantitatif, Kualitatif, dan $R \& D$. Bandung: Alfabeta.

Taylor, E. 2000. Using Folktales. Cambridge University Press.

Wainryb, R. 2003. Narrative activity for the Language Classroom. Cambridge University Press. 
